\title{
RESPONSE OF STREAM INVERTEBRATES TO A GLOBAL-WARMING THERMAL REGIME: AN ECOSYSTEM-LEVEL MANIPULATION'
}

\author{
IAN D. HogG ${ }^{2}$ AND D. Dudley Williams \\ Division of Life Sciences, Scarborough Campus, University of Toronto, 1265 Military Trail, Scarborough, Ontario,
} Canada MIC IA4

\begin{abstract}
We manipulated, in accord with global-warming predictions, the thermal regime of a permanent first-order stream near Toronto, Ontario, Canada. We examined the effects of a $2-3.5^{\circ} \mathrm{C}$ water-temperature increase on densities, biomass, species composition, and life histories of resident stream invertebrates. The stream was divided longitudinally at the source into two channels, one control and one experimental, and a before and after (BACI) design was employed such that one pre-manipulation year was followed by $2 \mathrm{yr}$ of the temperature manipulation. Changes in the experimental channel following commencement of the manipulation included: (1) decreased total animal densities, particularly Chironomidae (Diptera); (2) earlier onset of adult insect emergence; (3) increased growth rates and precocious breeding in Hyalella azteca (Amphipoda); (4) smaller size at maturity for Nemoura trispinosa (Plecoptera) and $\mathrm{H}$. azteca; and (5) altered sex ratios for Lepidostoma vernale (Trichoptera). These results partially corroborate previous laboratory and field studies. However, variation in the responses of individual target species to the manipulation was unexpected and may have been influenced by the genetic structure of local populations. We conclude that levels of gene flow among habitats may be critical to the degree of impact seen as a result of large-scale thermal perturbation (e.g., globâl warming).
\end{abstract}

Key words: adult emergence vs. temperature; animal densities vs. temperature; environmental temperature; field experiments; global warming; headwater streams; life histories; lotic macroinvertebrates; press perturbations; sex ratio vs. temperature; Sustainable Biosphere Initiative.

\section{INTRODUCTION}

The human-enhanced greenhouse effect (global warming) may result in one of the most rapid changes in temperature ever experienced by the earth's biota (Ojima et al. 1991, Esser 1992). Global-warming scenarios forecast increases in mean global air temperatures of $1.5-4.5^{\circ} \mathrm{C}$ following a doubling of atmospheric $\mathrm{CO}_{2}$ (IPCC 1990). For latitudes $>30^{\circ} \mathrm{N}$ the temperature increase may be even larger, particularly during winter (Hengeveld 1990). These temperatures will translate directly into changes in the temperature of running waters (Meisner et al. 1987). The need for research on the ecological consequences of such a climate change has received formal recognition through the Sustainable Biosphere Initiative of the Ecological Society of America (Lubchenco et al. 1991). Unfortunately, our ability to predict the consequences of elevated temperatures in lotic systems is limited by our lack of knowledge of natural phenomena (Sweeney et al. 1992).

Previous studies examining the effects of temperature on stream invertebrates have been restricted to laboratory experiments (Sweeney et al. 1986), studies using artificial outdoor channels (Rempel and Carter

\footnotetext{
1 Manuscript received 7 December 1994; revised 21 June 1995; accepted 10 July 1995.

${ }^{2}$ Present address: Centre Saint-Laurent, Environment Canada, 105 McGill, Montréal, Québec Canada H2Y 2 E7.
}

1987), or field surveys (Harper 1973). For example, it has been shown that increased temperatures may increase the respiratory rate of animals at the expense of growth (Sweeney and Schnack 1977) and fecundity (Sweeney 1978), and that significant changes in growth rate, adult size, and onset of adult insect emergence can occur as a result of relatively small shifts in temperature (e.g., $1-3^{\circ} \mathrm{C}$; Langford 1975 , Sweeney et al. 1986, Rempel and Carter 1987, Baker and Feltmate 1989). While such studies provide useful insights into the potential response of ecosystems, the direct extrapolation of their results to natural ecosystems is of ten confounded by the complexity of natural systems in responding to perturbation. Perhaps the most frequently advocated approach to evaluating the effects of such natural phenomena is the use of large temporaland spatial-scale field experiments (Hall et al. 1980, Odum 1990, Schindler 1990, Mooney 1991). However, to date there have been few attempts to undertake largescale field experiments in lotic systems, perhaps because of the considerable logistic challenges that are inherent to these habitats (Hairston 1989, Hogg et al. 1992, 1995).

Here, we present the results of a large temporal- and spatial-scale field experiment that was designed to test the effects of increased temperature on stream invertebrates. We heated a permanent first-order stream (Valley Spring) near Toronto, Ontario, Canada, in accord with global-warming predictions for the southern Great 


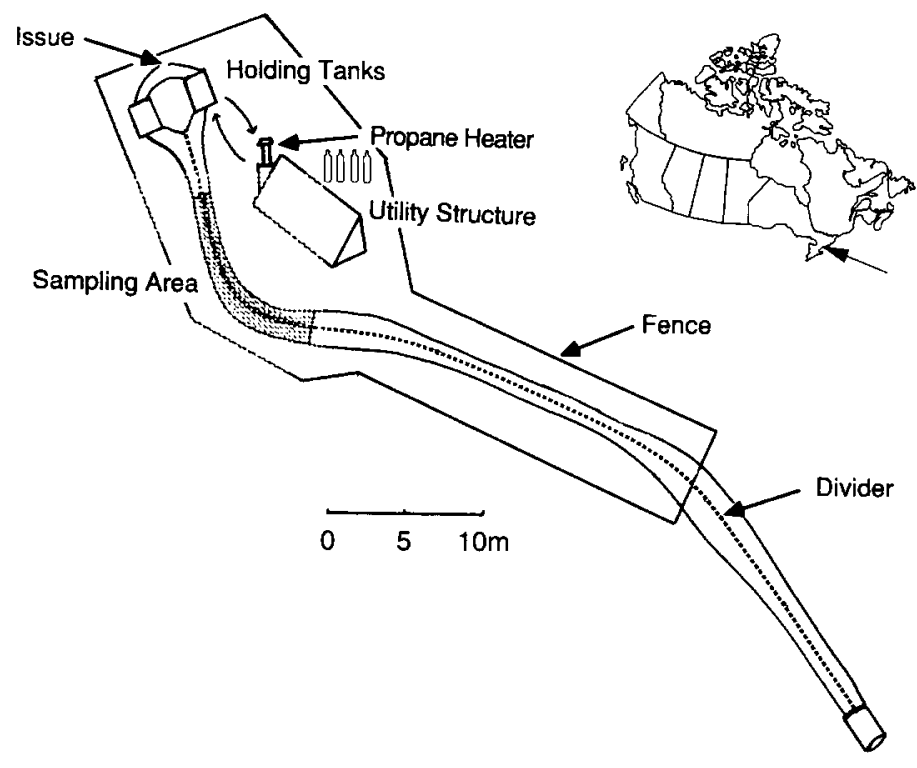

FIG. 1. Valley Spring field site showing experimental setup and sampling area. This small first-order stream is near Toronto, Ontario, Canada.

Lakes Region (Environment Canada, unpublished data), and examined the effects of the manipulation on total animal densities, biomass, and species composition. Further, we performed a detailed analysis of life history parameters for three resident species [Nemoura trispinosa Claassen (Plecoptera), Lepidostoma vernale (Banks) (Trichoptera), and Hyalella azteca (Saussure)(Amphipoda)] including: (1) growth patterns (immature to adult); (2) size at maturity; (3) fecundity (total number of eggs per female); and (4) emergence patterns for adult insects. The three species are widely distributed in eastern North America (Flint and Wiggins 1961, Strong 1972, Harper 1973), and represent taxa that are widely separated phylogenetically-a hemimetabolous insect, a holometabolous insect, and a crustacean, respectively. Both $N$. trispinosa and $L$. vernale tend to be restricted to cool-stream habitats $(0$ $20^{\circ} \mathrm{C}$; Flint and Wiggins 1961, Harper 1973), whereas H. azteca is found in a variety of habitats including cool streams and subtropical ponds (Edwards and Cowell 1992). Accordingly, we expected that $N$. trispinosa and $L$. vernale would respond negatively to increased temperature whereas $H$. azteca would be more adaptable in response to our experimental thermal regime.

On the basis of species' distributions and previous literature, we predicted that our temperature manipulation would result in: (1) decreased total animal densities, total biomass, and taxon richness (Odum 1985); (2) increased animal growth rates (shorter life cycle) (Odum 1985); (3) earlier emergence of adult insects (Langford 1975); (4) smaller size at maturity (Vannote and Sweeney 1980); and (5) decreased fecundity (Sweeney 1978).

\section{METHODS}

Study area

Valley Spring is a small $(1 \mathrm{~m}$ wide $\times 60 \mathrm{~m}$ long $\times$ $3.5 \mathrm{~cm}$ deep) first-order stream located in southern On- tario $\left(43^{\circ} 45^{\prime} \mathrm{N}, 79^{\circ} 15^{\prime} \mathrm{W} ; 150 \mathrm{~m}\right.$ elevation). The stream has a single point of issue $(25 \mathrm{~cm}$ across), and has an annual discharge of $1800-2300 \mathrm{~L} / \mathrm{h}$. The substratum consists of a mixture of coarse sand/silt with $\approx 20-30 \%$ aquatic macrophyte cover (primarily Nasturtium officinale). The life histories of resident invertebrate species and their temporal and spatial zonation are known based on 2 yr of pre-manipulation baseline data (Norton et al. 1988, Williams and Hogg 1988, I. D. Hogg and D. D. Williams, unpublished data). Annual water temperature ranges from $\approx 7$ to $18^{\circ} \mathrm{C}$ at the stream source. For further description see Williams and Hogg (1988).

\section{Experimental temperature manipulation}

The stream was divided longitudinally into two channels (one experimental and one control) of equal width using a galvanized metal strip set $15 \mathrm{~cm}$ into the substratum and rising $6 \mathrm{~cm}$ above the water surface (Fig. 1). At the source the flow was split, again using galvanized metal sheet, and each outflow was diverted through a $60-\mathrm{L}$ holding tank (set into the stream bed) before being returned to the system. Qualitative inspection of the stream before installation of the divider indicated no difference in physical characteristics (depth, current speed, temperature, substrate composition) between the left and right sides of the stream. Transfer of animals between channels following installation of the divider was unlikely as: (1) the galvanized strip was embedded in a clay layer $\approx 15 \mathrm{~cm}$ under the stream bed; (2) water levels never exceeded the top of the divider, including fluctuations resulting from large precipitation events (I. Hogg, personal observation); and (3) regular inspection of the divider revealed no animals on the divider above the water line.

A propane water heater (Constant Flo model PH-6D, Paloma Industries, Inc., Elk Grove Village, Illinois, USA) was used to increase temperatures in the experi- 
mental channel by $2^{\circ} \mathrm{C}$ in spring, summer, and fall and by $3.5^{\circ} \mathrm{C}$ in winter (based on predicted regional air temperature changes following a doubling of atmospheric $\mathrm{CO}_{2}$ ). To heat the experimental channel, water was pumped from the $60-\mathrm{L}$ holding tank at the stream issue to the water heater, and returned and mixed in the tank before entering the channel proper. To ensure continuous heating, the water pump was supplied with a $12-\mathrm{V}$ DC solar/battery backup system, in addition to the $120-\mathrm{V}$ $\mathrm{AC}$ main supply. Spot measurements of water temperature using a thermistor-thermometer (Model 8402-20, Cole-Parmer Instrument Company, Chicago, Illinois, USA) following commissioning of the heater, indicated no measurable transfer of heat between channels.

One sampling area (8-20 m downstream of the issue, Fig. 1) was selected for study based on a previously determined faunal zonation (Williams and Hogg 1988) and our ability to maintain the temperature differential $\left( \pm 0.2^{\circ} \mathrm{C}\right)$ between channels. Due to practical limitations our manipulation consisted of only one experimental channel and therefore lacked true replication, a problem common to many large-scale field experiments (Carpenter 1990, Eberhardt and Thomas 1991, Elser et al. 1995). Accordingly, we cannot state categorically that differences between channels were the result of our temperature manipulation, only that differences occurred between channels (Eberhardt 1976, Hurlbert 1984). To limit potential misinterpretations of the data we: (1) employed a "before and after" design (sensu Stewart-Oaten et al. 1986) such that one pre-manipulation year (June 1990-May 1991) was followed by 2 yr (June 1991-May 1993) of the temperature manipulation (thus covering two generations of univoltine species); and (2) used previous years' baseline data (Williams and Hogg 1988, I. D. Hogg and D. D. Williams, unpublished data) as a measure of inter-year variation.

\section{Effects of manipulation on immature stages: taxonomic composition, densities, biomass, and growth patterns}

Twenty benthic samples were taken from each channel every 2 mo using a modified Surber sampler $(0.01$ $\mathrm{m}^{2}$ sampling area, $53 \mu \mathrm{m}$ mesh) for a precision level of the standard-error-of-the-mean that is $<10 \%$ on $\log (x$ +1 )-transformed total counts (Elliott 1977). Samples were preserved and stained with Rose Bengal in the field, and then hand-sorted in the laboratory with the aid of a dissecting microscope, and identified to the lowest taxonomic level possible, in most cases genus and species (Williams and Hogg 1988). Taxon richness was measured as total number of species collected in each benthic sample. Community biomass was assessed as dry mass of the total animals collected in the individual benthic samples. Ten samples were used from each treatment for each sampling period.

To determine growth patterns, head-width measurements were taken from individuals of Nemoura tris- pinosa Claassen (Plecoptera: Nemouridae) and Lepidostoma vernale (Banks) (Trichoptera: Lepidostomatidae), and length measurements for individuals of $\mathrm{Hy}$ alella azteca (Saussure) (Amphipoda). Both the control and experimental thermal regimes in Valley Spring are to be found within the present distributional limits of all three species.

\section{Effects of manipulation on mature stages: size, fecundity, and emergence patterns}

Adults of the insects Nemoura trispinosa and Lepidostoma vernale were collected every 2-10 d using two pyramid emergence traps (Mundie 1956) fixed to the substratum in each channel (total area $=1.05 \mathrm{~m}^{2}$, $\approx 9 \%$ of total sampling area), for the pre-manipulation year and the $1 \mathrm{st} y \mathrm{r}$ of the manipulation. Five additional traps were placed in each channel in March 1993 (total area $=3.05 \mathrm{~m}^{2}, \approx 25 \%$ of total sampling area) for the 2nd yr of manipulation. For the amphipod Hyalella azteca, mature (length $>4 \mathrm{~mm}$, size at which eggs were first detected in females) individuals were collected in March and May of each year.

Individuals of each species were dry-weighed to the nearest $10^{-3} \mathrm{mg}$, using a Mettler M5 microbalance (Fisher Scientific, Toronto, Ontario, Canada). For the insects, individuals were sexed prior to weighing, and only individuals that were alive at the time of trapclearing were used, to prevent any bias as a result of decomposition within the trap. Individuals were stored in a $70 \%$ alcohol solution and analyzed following completion of the field experiment. Accordingly, intra-year comparisons (control vs. experimental) were processed simultaneously, and possible mass loss to the storage medium (Wen 1992) among years precluded any interyear comparison. Fecundity was determined by dissecting and counting the total number of eggs per female, for each species.

\section{Physical and chemical measurements}

Water temperatures were measured daily using maximum-minimum thermometers placed in each channel and daily means were calculated. This allowed us to determine the number of degree-days per channel (daily mean temperature $X$ number of days) to enable comparison with other studies examining the effects of temperature on the life histories of benthic invertebrates (Sweeney 1984). At monthly intervals conductivity, $\mathrm{pH}$, dissolved oxygen, and water temperature were measured in each channel using an ICM series 51100 water analyzer (Industrial and Chemical Measurements, Hillsboro, Oregon, USA) that recorded the environmental parameters simultaneously; each measurement was repeated 6 times.

\section{Data analysis}

For physical and chemical parameters, taxon richness, community biomass, and invertebrate densities, two-way repeated-measures analysis of variance (re- 
peated-measures ANOVA) were used to test for differences between location (control vs. experimental) and time of year (sampling month). This analysis was performed for each year of the study (1990-1991, 1991-1992, 1992-1993). For adult size (dry mass), and fecundity, a one-way analysis of variance (ANOVA), or analysis of covariance (ANCOVA) (for Hyalella), was used to test for differences between locations. Fixed-effects models were used for all analyses (Bennington and Thayne 1994). For all tests the raw data, or log-transformed values, were normally distributed (Wilk-Shapiro) and variances were homoscedastic (Bartlett's test, $P>0.05$ in all cases). Power analyses were only used where rejection of the null hypothesis was suspected but not indicated at the $\alpha=0.05$ level (Peterman 1990). An experimentwise adjustment of the error rate (Bonferroni) was used in cases where multiple tests of the same hypothesis were made (Rice 1988).

\section{RESULTS}

\section{Physical and chemical parameters}

Monthly spot-readings of water temperature (Fig. 2) following commencement of the manipulation were significantly higher in the experimental channel relative to the control (two-way repeated-measures ANOVA: $P<0.0001, F=5703$, $\mathrm{df}=1,131$; and $P<$ $0.0001, F=9306, \mathrm{df}=1,131$, manipulation years 1 and 2, respectively). Average annual temperature increases were $2.1^{\circ}$ and $2.4^{\circ} \mathrm{C}$ for manipulation years 1 and 2 , respectively. Readings prior to commencement of the manipulation were not significantly different $(P$ $=0.65, F=0.20, \mathrm{df}=1,109$ ). Annual degree-day accumulations (based on daily maximum and minimum water temperatures) were $743^{\circ} \mathrm{C}(15 \%)$ and $835^{\circ} \mathrm{C}$ (18\%) higher in the experimental channel relative to the control for the two manipulation years, respectively (Fig. 3). Variation in annual degree-day accumulations for the control channel was $<4 \%$. No significant differences were detected between channels relative to measures of dissolved oxygen, conductivity, or $\mathrm{pH}$ during the pre-manipulation year or following commencement of the manipulation (Fig. 2).

\section{Taxon richness, community biomass, and invertebrate densities}

A total of 72485 animals was collected over the $3 \mathrm{yr}$ study period representing 15 invertebrate orders and $\approx 50$ taxa. There was no evidence of extirpation of or colonization by new taxa following commencement of the manipulation, and all taxa had been recorded previously from Valley Spring (Williams and Hogg 1988, I. D. Hogg and D. D. Williams, unpublished data). Taxon richness (number of taxa/sample) was not significantly different (two-way repeated-measures ANOVA: $P>$ 0.53 in all cases) between channels for any of the three study years (Fig. 4). Measures of community biomass

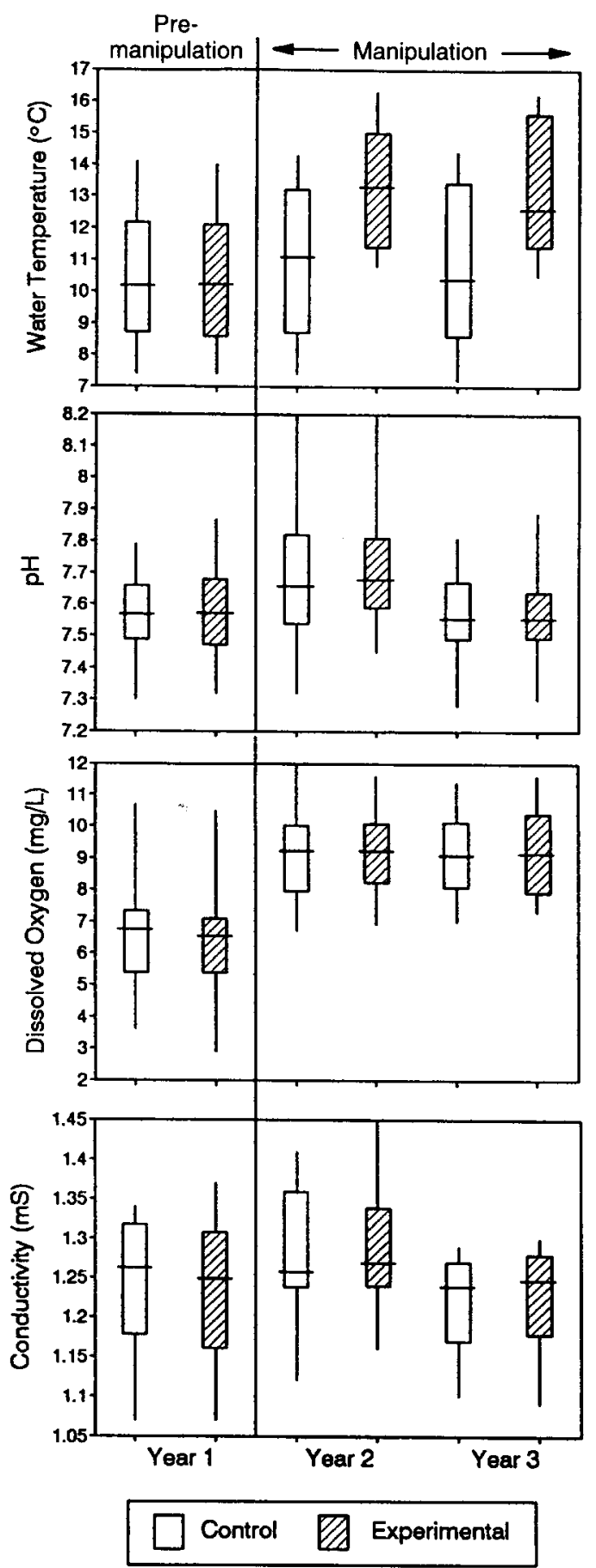

FIG. 2. Summary of monthly physical and chemical measures from control and experimental channels in Valley Spring. Annual means and range are presented for the premanipulation year and manipulation years 1 and 2 (June 1990-May 1993). Error bars represent the $25 \%$ and $75 \%$ quartiles. 
FIG. 3. Monthly degree-day accumulations (mean daily temperature $\times$ number of days) for pre-manipulation (June 1990-May 1991) and manipulation (June 1991-May 1993) years for control and experimental channels in Valley Spring. A line approximating the $10^{\circ} \mathrm{C}$-day level is shown for reference.

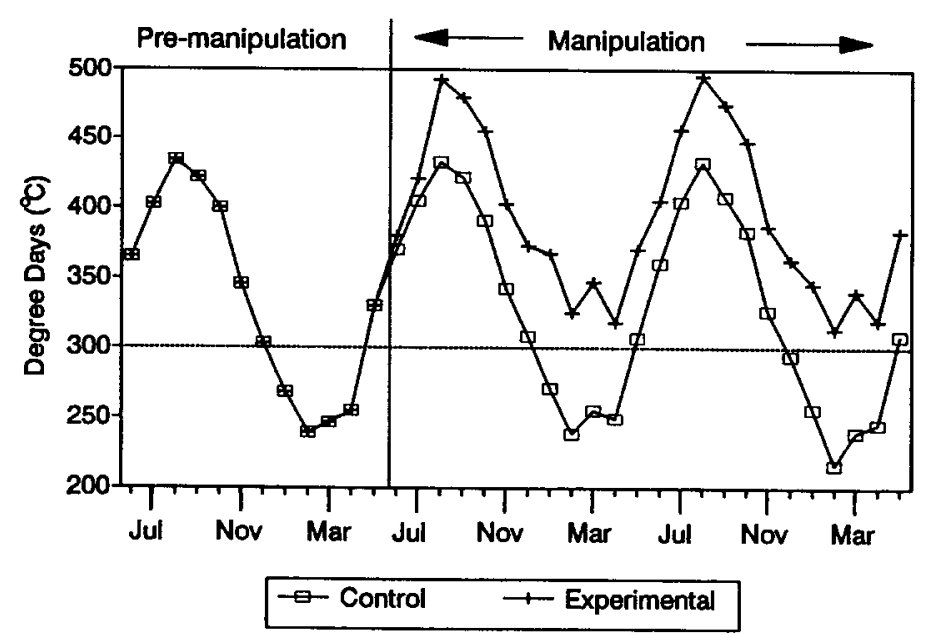

also were not significantly different (two-way repeatedmeasures ANOVA: $P>0.10$ in all cases) between channels for any of the three study years (Fig. 5).

Total invertebrate densities (Fig. 6) were significantly lower (two-way repeated-measures ANOVA: $P$ $=0.02, F=5.32$, df $=1,233$; and $P<0.0001, F=$ $19.88, \mathrm{df}=1,233)$ in the experimental channel relative to the control for the two manipulation years (12 and $23 \%$, respectively); densities were not significantly different between channels during the pre-manipulation year $(P=0.35, F=0.89$, df $=1,233)$. Virtually all of this difference appears to have been due to one taxon, the Chironomidae (Diptera) (Fig. 6; $P=0.0001$, $F=16.66, \mathrm{df}=1,233$, and $P<0.0001, F=51.05$, $\mathrm{df}=1,233$; for manipulation years 1 and 2 , respectively); densities were not significantly different during the pre-manipulation year $(P=0.45, F=0.57, \mathrm{df}=$ $1,233)$. Following removal of the Chironomidae from the analysis, no other significant density differences $(P$ $>0.53$ in all cases) were detected (Fig. 6). Further

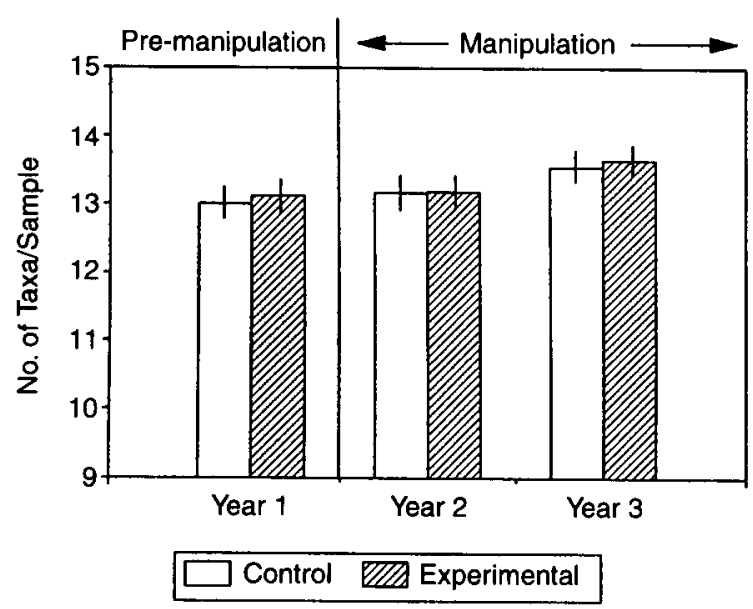

FIG. 4. Taxon richness (no. of taxa/sample; mean $\pm 1 \mathrm{SE}$ ) for the control and experimental channels for each study year. numerical analysis of individual taxa was complicated by the low densities of most species and the natural variability of their counts (Elliott 1977) between channels, and years. Accordingly, we caution that our ability to reliably detect changes in density $<20 \%$ for individual taxa was limited.

\section{Growth patterns}

Growth patterns for Hyalella azteca showed accelerated development, and breeding began up to 2 mo earlier in the experimental channel relative to the control, following commencement of the manipulation (Fig. 7). The mean size of animals for the months of March and May for both manipulation years was outside the range expected based on inter-year variation (Fig. 8). In contrast, no changes in nymphal/larval growth patterns for Nemoura trispinosa and Lepidostoma vernale were detected following the manipulation (Fig. 7), and differences in monthly mean sizes between channels (e.g., $L$. vernale) were within the range expected on the basis of year-to-year variation (Fig. 8).

Adult size

Mean body size (dry mass) for male and female $\mathrm{Nem}$ oura trispinosa was significantly lower $(P<0.01$ in all cases) in the experimental channel relative to the control for both years of the manipulation (Fig. 9). No significant differences were detected during the premanipulation year. An analysis of $N$. trispinosa head widths suggested that the reduction in body size was associated with a decrease in the dimensions of the animals (Fig. 10). No significant differences in mean body size (dry mass) were detected for individuals of Lepidostoma vernale between channels for any of the study years (Fig. 11).

The amphipod, Hyalella azteca, continues to grow after attaining maturity (indeterminate growth), hence, estimates of "size at maturity" will vary dependent on the time elapsed since maturation. As individuals in the experimental channel matured (commenced breed- 


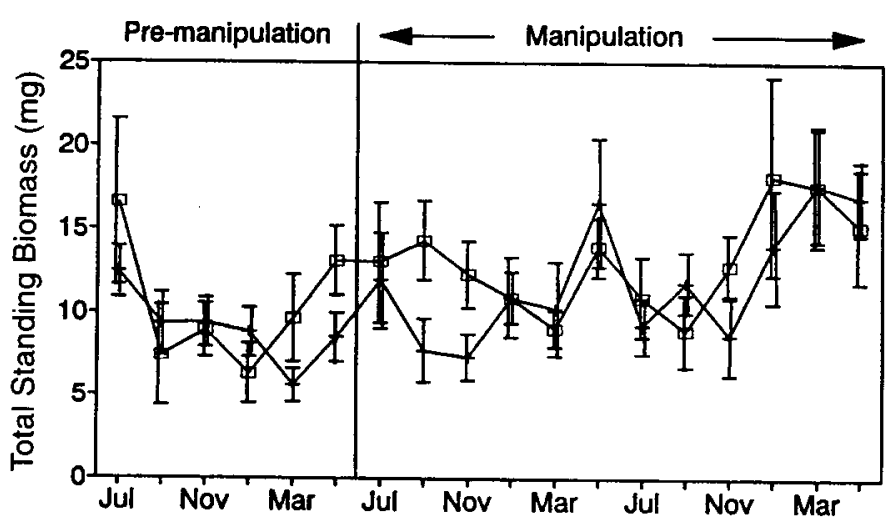

FIG. 5. Total biomass (per sample) for the control and experimental channels, for pre-manipulation and manipulation years in Valley Spring. Monthly means \pm 1 SE $(n=10$ samples per channel per month) are shown.

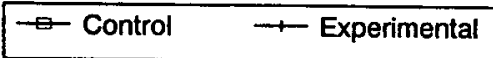

ing) earlier relative to the control channel (Fig. 7), direct comparisons between treatments were confounded by differences in the mean body lengths of mature individuals during our sampling periods (March, May). An analysis of covariance, for mature individuals (length $>4 \mathrm{~mm}$ ) with body length as the covariate ( $P$ $<0.0001$ in all cases) indicated a significantly lower body mass ( $P<0.006, F=8.54, \mathrm{df}=1,39$ ) for mature individuals in the experimental channel in May 1993 (Table 1).

\section{Fecundity}

Fecundity (number of eggs per female) for Lepidostoma vernale and Hyalella azteca was weakly ( $r^{2}=$ 0.23 and 0.32 , respectively) but significantly $(P<$ 0.001 in both cases), positively correlated with body size. Small sample sizes for egg-carrying Lepidostoma and Hyalella ( $n=80$ and 44 individuals, respectively) precluded direct comparisons between channels for each year. However, the similar mean body sizes at maturity between treatments for both species (Fig. 11, Table 1, respectively) would suggest similar fecundities (except in May 1993 when fecundity of $H$. azteca may have been lower in the experimental channel). For Nemoura trispinosa, egg development is, at least partially, dependent on adult feeding (Harper 1973); hence our collection method (emergence traps) likely preempted complete egg development. Of the $\approx 60 \mathrm{~N}$. trispinosa females examined, only one had fully developed eggs ( $n=563$ eggs). However, a positive relationship between body size and egg number has been well established for $N$. trispinosa (Harper 1973) and other Plecoptera species (Feltmate and Williams 1991). Accordingly, a reduction in body size for female $N$. trispinosa (Fig. 9) would likely be associated with reduced fecundity.

\section{Adult-insect emergence}

Emergence of adult Nemoura trispinosa and Lepidostoma vernale commenced 2 wk earlier, and the tim- ing for 50\% emergence and peak emergence also was 1-2 wk earlier in the experimental channel relative to the control (Figs. 12 and 13). Males and females for both species had similar emergence patterns. However, sex ratios for $N$. trispinosa shifted from male biased to female biased 1-2 wk earlier in the experimental channel (Fig. 12) Sex ratios for the two channels for $N$. trispinosa were similar (Chi-square test: $P=0.88$, following Yates' correction). By contrast, $L$. vernale was female biased $(3: 2)$ in the control channel but showed no sex bias $(1: 1)$ in the experimental channel (Chi-square test: $P=0.05$, following Yates' correction). Data from the 1991 and 1992 emergence periods suggest that $L$. vernale was female biased in Valley Spring ( $>3: 2, n=169$ individuals).

\section{Discussion AND CONCLUSIONS}

Large spatial- and temporal-scale field experiments such as our temperature manipulation of Valley Spring

TABLE 1. Summary of mean size for mature Hyalella azteca (Amphipoda) in control and experimental channels of Valley Spring (southern Ontario, Canada). Sizes shown are back-transformed (anti-log) adjusted means (ANCOVA with animal length as the covariate, $P<0.0001$ in all cases) for March and May of 1991 (pre-manipulation) and 1992, 1993 (manipulation).

\begin{tabular}{|c|c|c|c|c|c|c|}
\hline \multirow[b]{2}{*}{ Date } & \multicolumn{2}{|c|}{$\begin{array}{c}\text { Mean size } \\
\text { (mg dry mass) }\end{array}$} & \multirow[b]{2}{*}{$P$} & \multirow[b]{2}{*}{$F$} & \multirow[b]{2}{*}{$\mathrm{df}$} & \multirow[b]{2}{*}{$n \dagger$} \\
\hline & Contr. & Exper. & & & & \\
\hline \multicolumn{7}{|c|}{ Pre-manipulation } \\
\hline $\begin{array}{l}\text { Mar } 1991 \\
\text { May } 1991\end{array}$ & $\begin{array}{l}.2335 \\
.3302\end{array}$ & $\begin{array}{l}.2552 \\
.3154\end{array}$ & $\begin{array}{l}.91 \\
.38\end{array}$ & $\begin{array}{l}.01 \\
.78\end{array}$ & $\begin{array}{l}1,37 \\
1,39\end{array}$ & $\begin{array}{l}20 \\
21\end{array}$ \\
\hline \multicolumn{7}{|l|}{ Manipulation } \\
\hline $\begin{array}{l}\text { Mar } 1992 \\
\text { May } 1992 \\
\text { Mar } 1993 \\
\text { May } 1993\end{array}$ & $\begin{array}{l}.2773 \\
.5336 \\
.3156 \\
.5670\end{array}$ & $\begin{array}{l}.2684 \\
.5804 \\
.3138 \\
.4782\end{array}$ & $\begin{array}{l}.57 \\
.11 \\
.93 \\
.006^{*}\end{array}$ & $\begin{array}{r}.34 \\
2.70 \\
.01 \\
8.54\end{array}$ & $\begin{array}{l}1,45 \\
1,37 \\
1,37 \\
1,39\end{array}$ & $\begin{array}{l}24 \\
20 \\
20 \\
21\end{array}$ \\
\hline
\end{tabular}

* Significant at $\alpha=0.05$ (adjusted for multiple-comparisons $\alpha^{\prime}=0.008$ ).

$\dagger n=$ number of observations per treatment. 

sample) for the control and experimental channels, for pre-manipulation and manipulation years in Valley Spring. Monthly means $\pm 1 \mathrm{SE}$ $(n=20)$ are shown for: total animal densities; total Chironomidae densities; and total densities with Chironomidae removed. Standard error bars are less than or equal to line markers unless otherwise indicated.
FIG. 6. Animal densities (no. of animals/

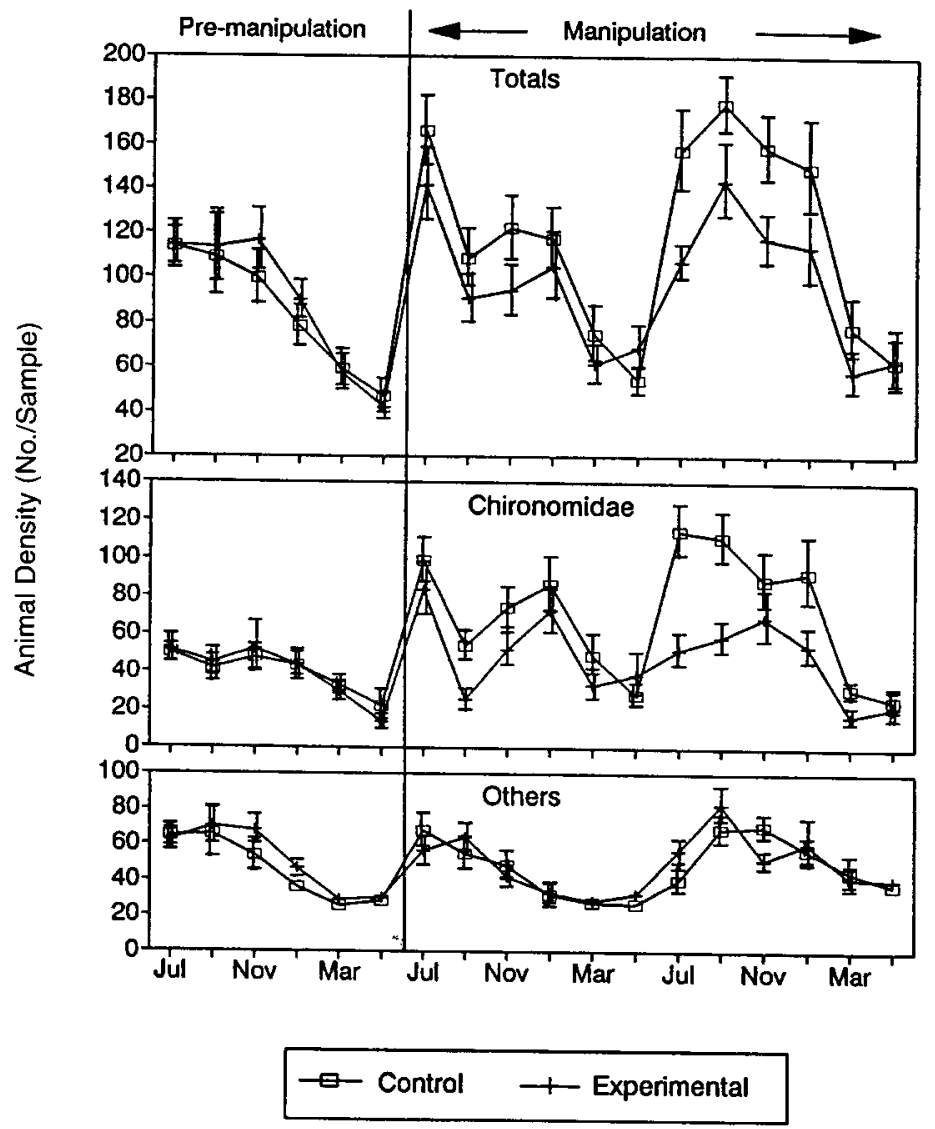

are critical for (1) evaluating the response potential of natural ecosystems to significant environmental perturbations such as global warming (Schindler 1987, Carpenter 1989); and (2) testing hypotheses concerning the effects of teriperature on natural populations (Vannote and Sweeney 1980, Atkinson 1994). One of the major challenges of large-scale field experiments, however, is discerning the effects of modest perturbations from natural, background variation (Carpenter 1989, Osenberg et al. 1994). In this study we were able to demonstrate that a relatively small change (i.e., 2.1$2.4^{\circ} \mathrm{C}$ mean annual increase) in the temperature of a natural stream ecosystem can result in measurable responses by the resident invertebrate populations. Specifically, we found reductions in total densities, increased growth rates, earlier emergence of adult insects, precocious breeding, decreases in body size at maturity, and altered sex ratios in response to our experimental thermal regime.

A reduction in total animal densities following commencement of our manipulation is similar to findings reported from other perturbed systems (e.g., Hall et al. 1980, Hogg and Norris 1991) and, from a theoretical perspective, is hypothesized to be a consequence of less efficient use of available resources (increased respiration/production ratios) within the system (Busch and Fisher 1981, Odum 1985). The lower densities of chironomid Diptera in the experimental channel (Fig. 6) is consistent with previous surveys that suggest that certain taxa (e.g., Orthocladiinae) are cool-water affiliates (Mackay 1969, Ward and Williams 1986). Accordingly, it is possible that temperatures in the experimental channel may have approached the upper thermal limits for some species in Valley Spring.

Despite the lower total densities in the experimental channel relative to the control, there was no evidence of a change in species richness or community biomass (Figs. 4 and 5). Sweeney et al. (1986) found, under laboratory conditions, that a temperature increase of $6^{\circ} \mathrm{C}$, although responsible for high mortalities (99\%) in Soyedina carolinensis Claassen (Plecoptera), did not eliminate all individuals. Species persistence in response to our temperature increase of $2-3.5^{\circ} \mathrm{C}$ was therefore not surprising. Similarly, lower densities of Chironomidae in the experimental channel (Fig. 6) were undetectable in our biomass analyses, as this taxon contributes relatively little $(<5 \%)$ to the total production of our sampled area (Williams and Hogg 1988).

The response of individual species to the manipulation was variable. For example, reductions in body size (dry mass) at maturity were recorded for Nemoura trispinosa $(10-25 \%)$ and Hyalella azteca $(16 \%$ in the 

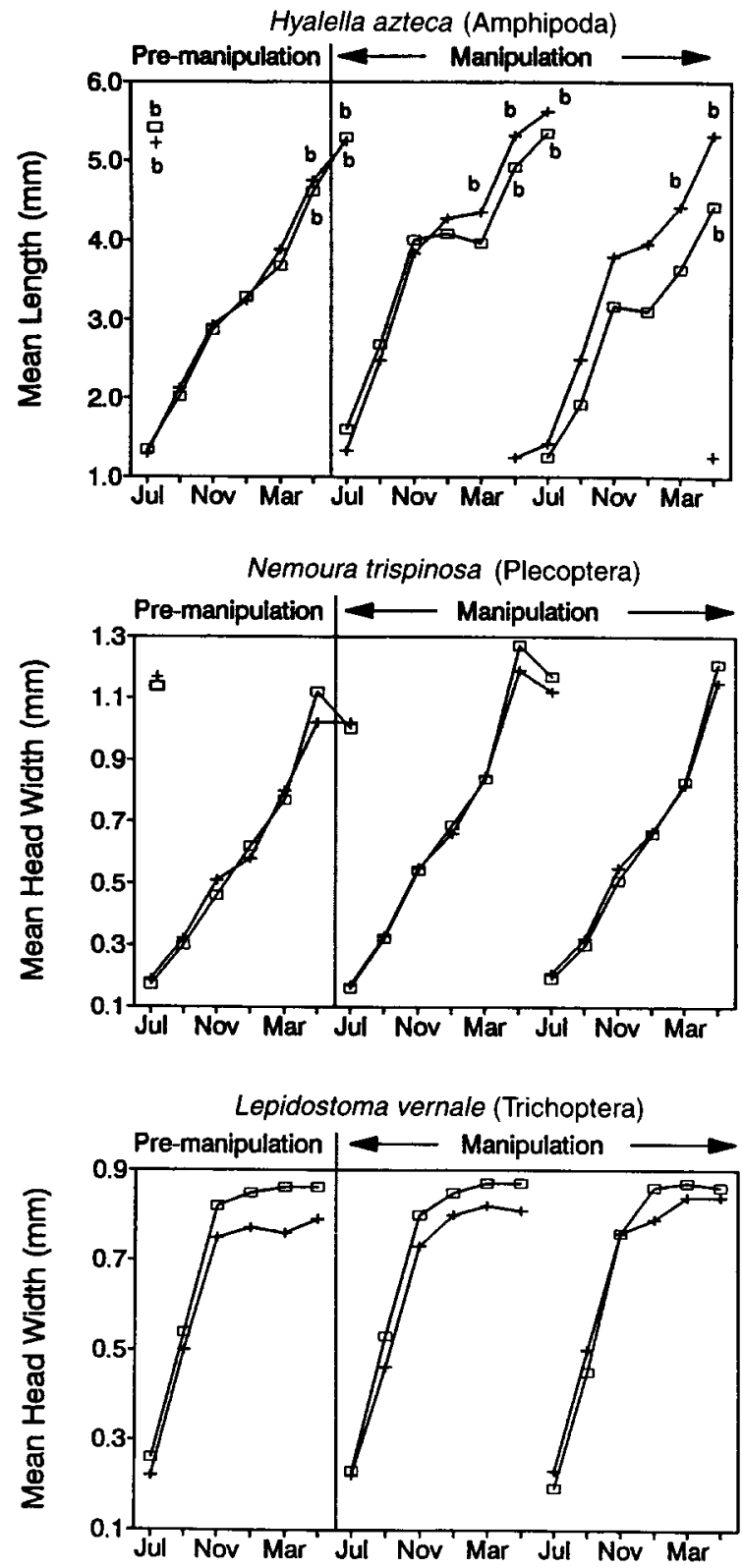

\section{๑- Control † Experimental}

FIG. 7. Mean body length or head widths for three resident species for each sampling month in control and experimental channels in Valley Spring. Standard error bars are less than, or equal to, line markers; " $b$ " indicates egg-carrying females present.

2nd yr of manipulation) (although not for Lepidostoma vernale $(<5 \%)$ ). These results corroborate previous laboratory-based experiments (Sweeney et al. 1986, Rempel and Carter 1987), field observations (Harper 1973), and conceptual models (Vannote and Sweeney 1980, Atkinson 1994) that suggest that a reduced body size at maturity will be incurred by individuals reared
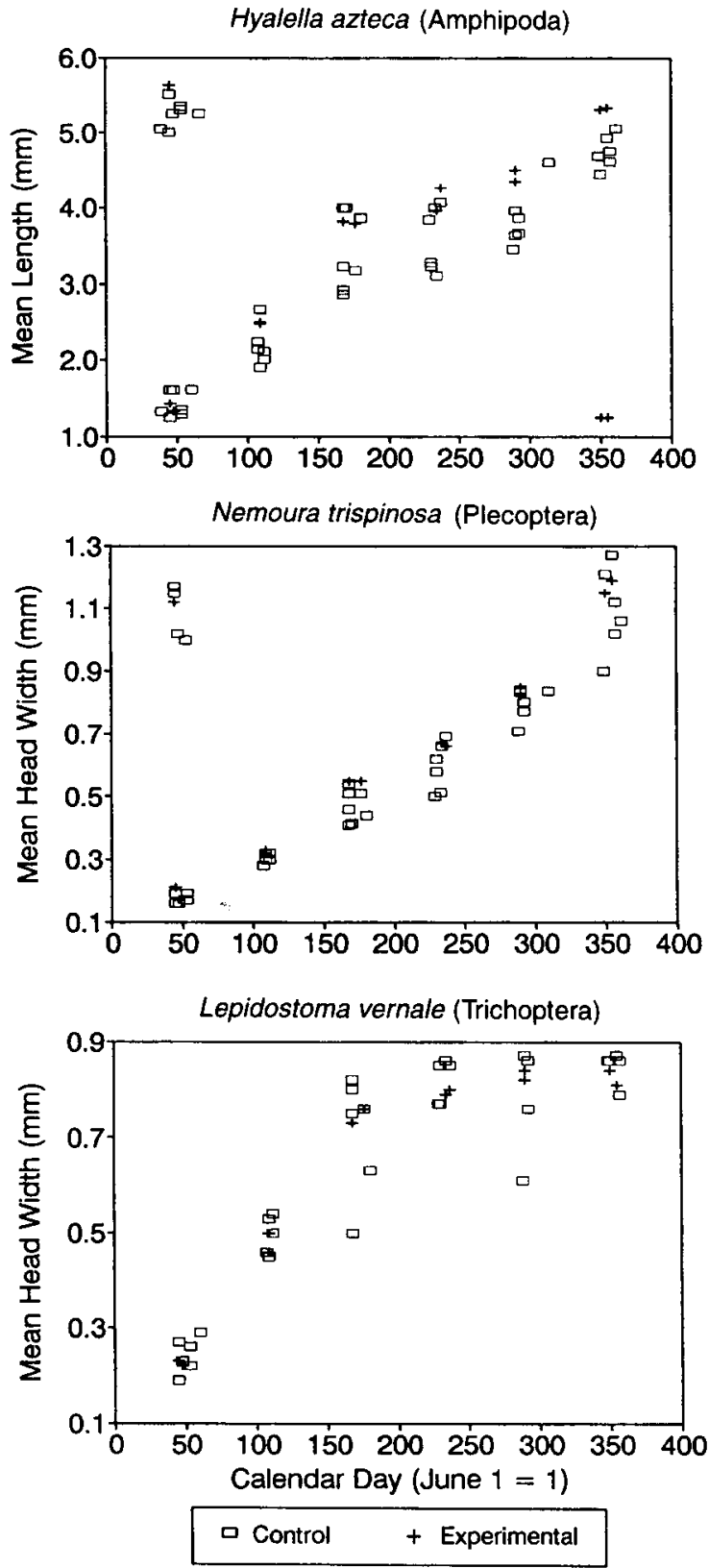

FIG. 8. Inter-year comparison of mean body lengths and head widths for three resident species for each sampling month (plotted per calendar day). Control measures are from 1985-1986 (Williams and Hogg 1988), 1986-1987 (I. D. Hogg and D. Williams, unpublished data), and 1990-1993 (present study, pre-manipulation year [control and experimental channels] and manipulation years 1 and 2 [control channel]). Experimental measures are from manipulation years 1 and 2 (experimental channel, 1991-1993). Standard error bars are less than, or equal to, line markers.

at higher, non-lethal, temperatures. However, the lack of a detectable response for $L$. vernale suggests that responses to small shifts in temperature are not universal and may be more prevalent within particular phylogenetic groups (e.g., hemimetabolous insects). 


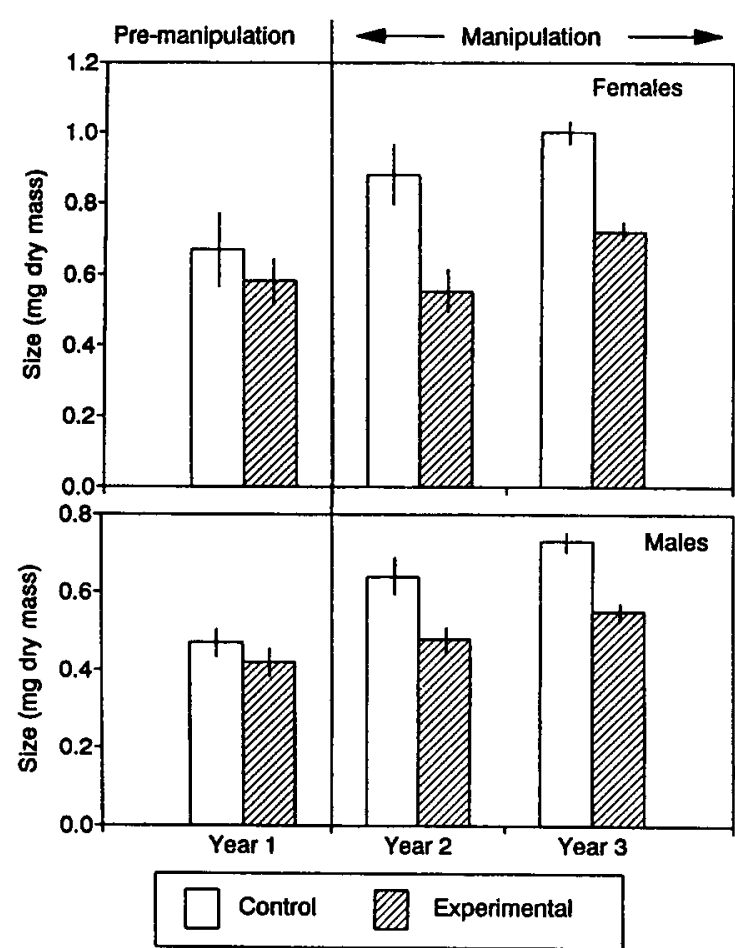

FIG. 9. Mean size ( \pm 1 SE) of adult male and female Nemoura trispinosa (Plecoptera) emerging from control and experimental channels in Valley Spring, 1991-1993.

The 2-wk advance in the onset of emergence of adults for both Lepidostoma vernale and Nemoura trispinosa (Figs. 12 and 13) was similar to results obtained for populations downstream from heated effluent from a power station (Langford 1975), and was expected as a consequence of more rapid development of adult tissue (Sweeney 1984). Both species exhibited a sexbased size dimorphism (Figs. 9 and 11), which is often associated with protandrous species (Nylin et al. 1993). Protandry (differential timing of male and female emergence) is often thought to restrict breeding within populations (Butler 1984), although this appears unlikely for populations in Valley Spring as there was considerable overlap in emergence periods between the sexes and both had peak emergence during the same week (Figs. 12 and 13). However, the earlier (1-2 wk) male peak in the experimental channel relative to the female peak in the control channel may promote inter-breeding among habitats of differing thermal regimes by allowing sufficient time for dispersal to geographically separated locations. A preliminary genetic analysis of Nemoura trispinosa populations in southern Ontario (Hogg et al. 1995) indicates little differentiation among populations separated by up to $150 \mathrm{~km}$, suggesting gene flow is occurring among populations. A comprehensive analysis of insect dispersal pathways (e.g., Williams and Williams 1993) together with an analysis of the genetic structure of their populations (e.g., Jackson and Resh 1992) would further address this issue.

Smaller individuals of adult $N$. trispinosa from the experimental channel may suffer decreased fitness as a result of size-based mate selection by females (Huber 1993, Fairbairn and Preziosi 1994), and may be disadvantaged when mating under unfavorable weather conditions (e.g., high winds; Harvey and Walsh 1993). Size also may serve as a reproductive isolating mechanism, if larger individuals are precluded from breeding with smaller individuals because of any problems with "mechanical fitting" of reproductive structures.

Male-biased sex ratios (3:2) were similar in both the control and experimental channels for $N$. trispinosa (Fig. 12). However, sex ratios for $L$. vernale shifted from female biased $(3: 2)$ to unbiased $(1: 1)$ in the experimental channel. We are aware of no work examining temperature-dependent sex determination in aquatic invertebrates although such differences are well known from the herpetological and ichthyological literature (e.g., Conover and Kynard 1981, Gutzke and Crews 1988).

Thus far, we have considered the short-term responses of species to our experimental thermal regime. However, observed decreases in animal densities (Chi-

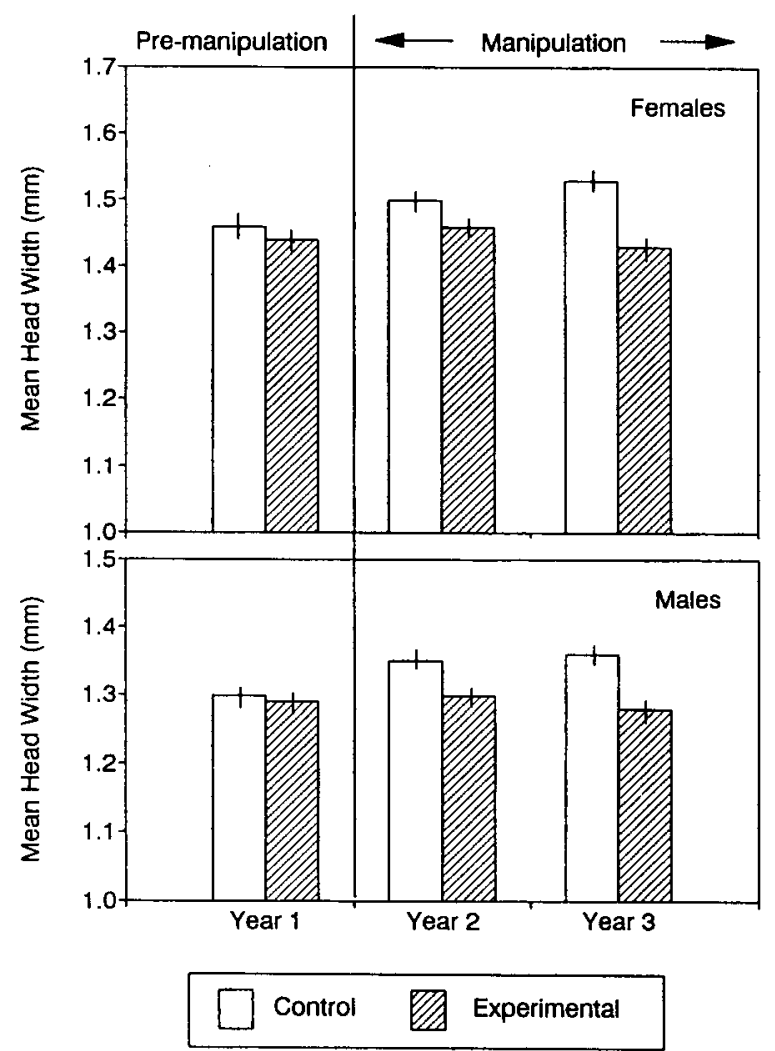

FIG. 10. Mean head width ( $\pm 1 \mathrm{SE}$ ) of male and female Nemoura trispinosa emerging from control and experimental channels in Valley Spring, 1991-1993. 


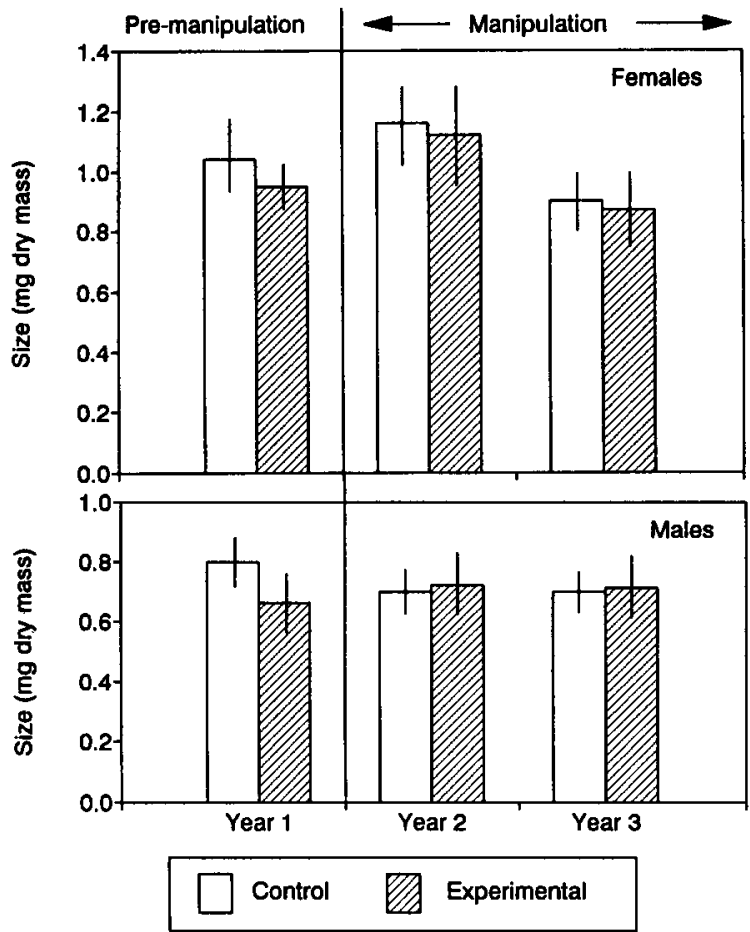

Fig. 11. Mean size ( $\pm 1 \mathrm{SE})$ of adult male and female Lepidostoma vernale (Trichoptera) emerging from control and experimental channels in Valley Spring, 1991-1993.

ronomidae), size at maturity/fecundity ( $N$. trispinosa, $H$. azteca), and altered sex ratios ( $L$. vernale) have serious implications for the persistence of species within a given habitat or geographic region (Vannote and Sweeney 1980). Projecting the long-term consequences of a sustained temperature increase (e.g., global warming) is highly speculative, and will depend on species' abilities to adapt to novel conditions. This, in turn, will depend to a large extent on the genotypic and pheno- typic variability that exists within species for key traits underlying their distribution (Sweeney et al. 1992). Recent evidence suggests that some lotic species consist of genetically distinct subpopulations, each adapted to local conditions (Jackson and Resh 1992). Consequently variability within individual populations may be limited, particularly at the margins of species' distributions (Sweeney et al. 1992, Hoffmann and Blows 1993). Accordingly, the existence of adequate genetic variability and gene flow among populations to facilitate adaptation, or of "source" populations to colonize marginal habitats (Pulliam 1988), may be critical. In evolutionary terms, the relatively short duration of the present experiment (two generations) was unlikely to have caused an evolutionary (adaptive) response in resident species (Hoffman and Blows 1993). However, the lack of aerial isolation between our experimental and control channels would have allowed colonization and/ or gene flow by aerially dispersing species from a potential "source" habitat (e.g., the control channel). This may have resulted in more conservative responses for some species (e.g., insects, $N$. trispinosa, $L$. vernale), than would be expected under conditions of whole-scale thermal perturbation (e.g., global warming), where potential source populations may not be available. If anthropogenic land-use patterns continue as at present, resulting in highly fragmented natural habitats (Vitousek 1994), then species with limited dispersal abilities (e.g., non-insects, short-lived adults), may be less able to adapt to change relative to their more actively dispersing counterparts. These differential responses of species to thermal perturbation and the corresponding changes in species' interactions may cause considerable disruption to lotic systems.

\section{Summary and recommendations for future studies}

The results of our temperature manipulation corroborated most of our a priori predictions (e.g., reductions

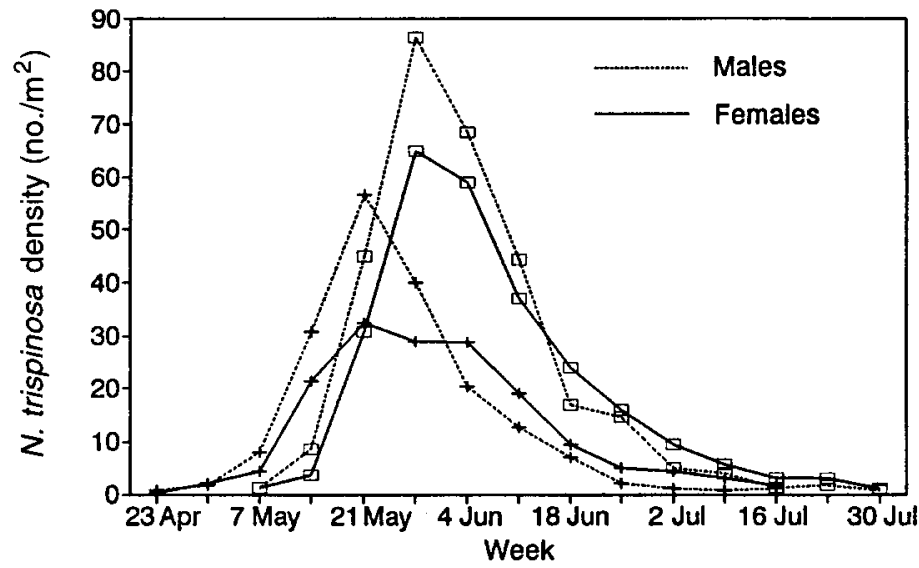

$\square$ Control
+ Experimental
FIG. 12. Weekly emergence for male and female Nemoura trispinosa (Plecoptera) from control and experimental channels of Valley Spring (23 April-30 July 1993). 
Fig. 13. Weekly emergence for male and female Lepidostoma vernale (Trichoptera) from control and experimental channels of Valley Spring (23 April 23-30 July 1993).

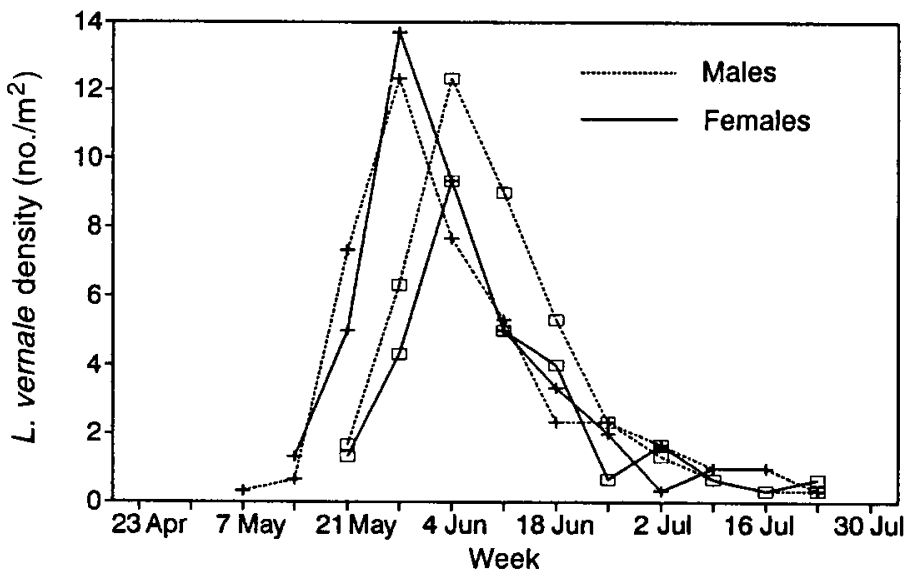

든 + Experimental in total animal densities, reduced size at maturity, faster development), but were variable in magnitude among species. The possibility that species' responses may have been influenced by the genetic structure of their populations has serious consequences for the conservation of natural species assemblages. Further avenues of research that should be pursued in the near future include: (1) comprehensive analyses of the genetic structure (variability, levels of gene flow) for a range of aquatic taxa; (2) an assessment of the dispersal abilities and pathways for aquatic insects and non-insects; (3) an evaluation of size-dependent mate selection in protandrous taxa, to ascertain the potential for any temperature-based reproductive isolating mechanisms; and (4) a study of the potential for temperature-dependent sex determination on developing eggs, embryos, and larvae for a range of taxa.

We conclude that changes in life history parameters such as size at maturity, timing of emergence, and adult sex ratios are likely to be more sensitive indicators of small, gradual shifts in environmental temperature (e.g., global warming) than are changes in taxon composition, species richness, community biomass, or densities of individual taxa.

We speculate that the dispersal of individuals (i.e., gene flow) among habitats with differing temperature profiles may offer potential solutions to atypical thermal regimes such as those predicted as a consequence of global warming. The consequences of habitat loss and/or fragmentation in view of impending global environmental change may therefore have serious consequences for natural stream assemblages. Many of our large rivers have already lost their original faunas as a result of anthropogenic activities, and Zwick (1992) cautions that the faunas of upland (headwater) streams are now also at risk. Accordingly, the ability of lotic systems to adapt to environmental change may already be reduced. We advocate maintaining a natural thermal diversity of lotic and lentic habitats (e.g., hot/cold springs, temporary and permanent streams/ponds) within a geographic region, thus maintaining genetic diversity and facilitating natural gene flow among populations.

\section{ACKNOWLEDGMENTS}

We thank Drs. A. C. Benke, N. C. Collins, J. M. Eadie, J. Holmes, M. C. Molles, Jr., W. G. Sprules, and an anonymous reviewer for constructive comments on the manuscript. $S$. Barker, R. Boonstra, S. A. Butt, C. J. Duvall, B. W. Feltmate, B. G. Fraser, P. Mathur, A. Quin, M. R. Smith, A. F. TavaresCromar, L. C. Taylor, N. E. Williams, and A. Wong provided assistance in the field and/or laboratory. Superior Propane Ltd. (Whitby, Ontario) delivered a constant supply of fuel cylinders through rough terrain, and often during adverse meterological events. Research was funded through a Natural Sciences and Engineering Research Council of Canada (NSERC) operating grant to D. D. Williams. Additional support was provided through an Ontario Graduate Scholarship, a University of Toronto Open Fellowship, and a Visiting Fellowship in a Canadian Government Laboratory to I. D. Hogg.

\section{Literature Cited}

Atkinson, D. 1994. Temperature and organism size-a biological law for ectotherms? Advances in Ecological Research 25:1-58.

Baker, R. L., and B. W. Feltmate. 1989. Depth selection by larval Ischnura verticalis (Odonata: Coenagrionidae): effects of temperature and food. Freshwater Biology 22:169175.

Bennington, C. C., and W. V. Thayne. 1994. Use and misuse of mixed model analysis of variance in ecological studies. Ecology 75:717-722.

Busch, D. E., and S. G. Fisher. 1981. Metabolism of a desert stream. Freshwater Biology 11:301-307.

Butler, M. G. 1984. Life histories of aquatic insects. Pages 24-55 in V. H. Resh, and D. M. Rosenberg, editors. The ecology of aquatic insects. Praeger, New York, New York, USA.

Carpenter, S. R. 1989. Replication and treatment strength in whole-lake experiments. Ecology 70:453-463.

- 1990. Large-scale perturbations: opportunities for innovation. Ecology 71:2038-2043.

Conover, D. O., and B. E. Kynard. 1981. Environmental sex 
determination: interaction of temperature and genotype in a fish. Science 213:577-579.

Eberhardt, L. L. 1976. Quantitative ecology and impact assessment. Journal of Environmental Management 42:1-31.

Eberhardt, L. L., and J. M. Thomas. 1991. Designing environmental field studies. Ecological Monographs 61:5373.

Edwards, T. D., and B. C. Cowell. 1992. Population dynamics and secondary production of Hyalella azteca (Amphipoda) in Typha stands of a subtropical Florida lake. Journal of the North American Benthological Society 11:69-79.

Elliott, J. M. 1977. Some methods for the statistical analysis of samples of benthic invertebrates. Freshwater Biological Association Scientific Publication 25.

Elser, J. J., C. Luecke, M. T. Brett, and C. R. Goldman. 1995. Effects of food web compensation after manipulation of rainbow trout in an Oligotrophic lake. Ecology 76:52-69.

Esser, G. 1992. Implications of climate change for production and decomposition in grasslands and coniferous forests. Ecological Applications 2:47-54.

Fairbairn, D. J., and R. F. Preziosi. 1994. Sexual selection and the evolution of allometry for sexual size dimorphism in the water strider, Aquarius remigis. American Naturalist 144:101-118.

Feltmate, B. W., and D. D. Williams. 1991. Evaluation of predator-induced stress on field populations of stoneflies (Plecoptera). Ecology 72:1800-1806

Flint, O. S., Jr., and G. B. Wiggins. 1961. Records and descriptions of North American species in the genus Lepidostoma, with a revision of the Vernalis group (Trichoptera: Lepidostomatidae). Canadian Entomologist 93:279-297.

Gutzke, W. H. N., and D. Crews. 1988. Embryonic temperature determines adult sexuality in a reptile. Nature $\mathbf{3 3 2}$ 832-834

Hairston, N. G., Sr. 1989. Ecological experiments: purpose, design and execution. Cambridge University Press. Cambridge, England.

Hall, R. J., G. E. Likens, S. B. Fiance, and G. R. Hendry. 1980. Experimental acidification of a stream in the Hubbard Brook Experimental Forest, New Hampshire. Ecology 61:976-989.

Harper, P. P. 1973. Life histories of Nemouridae and Leuctridae in southern Ontario (Plecoptera). Hydrobiologia 41 309-356.

Harvey, I. F., and K. J. Walsh. 1993. Fluctuating asymmetry and lifetime mating success are correlated in males of the damselfly Coenagrion puella (Odonata: Coenagrionidae). Ecological Entomology 18:198-202.

Hengeveld, H. G. 1990. Global climate change: implications for air temperature and water supply in Canada. Transactions of the American Fisheries Society 119:176-182.

Hoffmann, A. A., and M. W. Blows. 1993. Evolutionary genetics and climate change: will animals adapt to global warming? Pages 165-178 in P. M. Kareiva, J. G. Kingsolver, and R. B. Huey, editors. Biotic interactions and global change. Sinauer, Sunderland, Massachusetts, USA.

Hogg, I. D., and R. H. Norris. 1991. Effects of runoff from land clearing and urban development on the distribution and abundance of macroinvertebrates in pool areas of a river. Australian Journal of Marine and Freshwater $\mathrm{Re}$ search 42:507-518.

Hogg, I. D., D. D. Williams, J. M. Eadie, and S. A. Butt. 1995. The consequences of global warming for stream invertebrates: a field simulation. Journal of Thermal Biology 20: 199-206.

Hogg, I. D., D. D. Williams, and B. W. Feltmate. 1992. Freshwater springs: ideal sites for large-scale temporal and spatial manipulations of aquatic systems. Pages 189-198 in J. A. Stanford and J. J Simons, editors. Proceedings of the First International Conference on Ground Water Ecology.
American Water Resources Association, Bethesda, Maryland, USA

Huber, B. A. 1993. Genital mechanics and sexual selection in the spider Nesticus cellulanus (Araneae: Nesticidae). Canadian Journal of Zoology 71:2437-2447.

Hurlbert, S. H. 1984. Pseudoreplication and the design of ecological field experiments. Ecological Monographs 54: 187-211.

IPCC [Intergovernmental Panel on Climate Change]. 1990. Scientific assessment of climate change. Report of Working Group 1. World Meteorological Organization, Geneva, Switzerland

Jackson, J. K., and V. H. Resh. 1992. Variation in genetic structure among populations of the caddisfly Helicopsyche borealis from three streams in northern California, U.S.A Freshwater Biology 27:29-42.

Langford, T. E. 1975. The emergence of insects from a British river, warmed by power station cooling-water. II. The emergence patterns of some species of Ephemeroptera, Trichoptera and Megaloptera in relation to water temperature and river flow, upstream and downstream of the coolingwater outflows. Hydrobiologia 47:91-133.

Lubchenco, J., A. M. Olson, L. B. Brubaker, S. R. Carpenter, M. J. Holland, S. P. Hubbell, S. A. Levin, J. A. MacMahon, P. A. Matson, J. M. Melillo, H. A. Mooney, C. H. Peterson, H. R. Pulliam, L. A. Real, P. J. Regal, and P. G. Risser 1991. The Sustainable Biosphere Initiative: an ecological research agenda. Ecology 72:371-412.

Mackay, R. J. 1969. Aquatic insect communities of a small stream on Mont St. Hilaire, Quebec. Journal of the Fisheries Research Board of Canada 26:1157-1183.

Meisner, J. D., J. L. Goodier, H. A. Regier, B. J. Shuter, and W. J. Christie. 1987. An assessment of the effects of climate warming on Great Lakes basin fishes. Journal of Great Lakes Research 13:340-352.

Mooney, H. A. 1991. Biological response to climate change an agenda for research. Ecological Applications 1:1 12-1 17

Mundie, J. H. 1956. Emergence traps for aquatic insects. Internationale Vereinigung für Theoretische und Angewandte Limnologie, Verhandlungen 7:1-13.

Norton, R. A., D. D Williams, I. D. Hogg, and S. C. Palmer. 1988. Biology of the oribatid mite Mucronothrus nasalis (Acari: Oribatida: Trhypochthoniidae) from a small coldwater springbrook in eastern Canada. Canadian Journal of Zoology 66:622-629.

Nylin, S., C. Wiklund, and P-O. Wickman. 1993. Absence of trade-offs between sexual size dimorphism and early male emergence in a butterfly. Ecology 74:1414-1427.

Odum, E. P. 1985. Trends expected in stressed ecosystems. BioScience 35:419-422.

- 1990. Field experimental tests of ecosystem level hypotheses. Trends in Ecology and Evolution 5:204-205.

Ojima, D. S., T. G. F. Kittel, T. Rosswall, and B. H. Walker. 1991. Critical issues for understanding global change effects on terrestrial ecosystems. Ecological Applications 1: 316-325.

Osenberg, C. W., R. J. Schmitt, S. J. Holbrook, K. E. AbuSaba, and A. R. Felgal. 1994. Detection of environmental impacts: natural variability, effect size, and power analysis. Ecological Applications 4:16-30.

Peterman, R. M. 1990. Statistical power analysis can improve fisheries research and management. Canadian Journal of Fisheries and Aquatic Sciences 47:2-15.

Pulliam, H. R. 1988. Sources, sinks, and population regulation. American Naturalist 132:652-661.

Rempel, R. S., and J. C. H. Carter. 1987. Temperature influences on adult size, development, and reproductive potential of aquatic Diptera. Canadian Journal of Fisheries and Aquatic Sciences 44:1743-1752. 
Rice, W. R. 1988. Analyzing tables of statistical tests. Evolution 43:223-225.

Schindler, D. W. 1987. Detecting ecosystem responses to anthropogenic stress. Canadian Journal of Fisheries and Aquatic Sciences 44:6-25.

- 1990. Experimental perturbations of whole lakes as tests of hypotheses concerning ecosystem structure and function. Oikos 57:25-41.

Stewart-Oaten, A., W. Murdoch, and K. Parker. 1986. Environmental impact assessment: "pseudoreplication" in time? Ecology 67:929-940.

Strong, D. R. 1972. Life history variation among populations of an amphipod (Hyalella azteca). Ecology 53:1103-1111.

Sweeney, B. W. 1978. Bioenergetic and developmental response of a mayfly to thermal variation. Limnology and Oceanography 23:461-477.

1984. Factors influencing life-history patterns of aquatic insects. Pages 56-100 in V. H. Resh and D. M. Rosenberg, editors. The ecology of aquatic insects. Praeger, New York, New York, USA.

Sweeney, B. W., J. K. Jackson, J. D. Newbold, and D. H. Funk. 1992. Climate change and the life histories and biogeography of aquatic insects in eastern North America. Pages 143-176 in P. Firth and S. G. Fisher, editors. Global climate change and freshwater ecosystems. Springer-Verlag, New York, New York, USA.

Sweeney, B. W., and J. A. Schnack. 1977. Egg development, growth, and metabolism of Sigara alternata (Say) (He- miptera: Corixidae) in fluctuating thermal environments. Ecology 58:265-277.

Sweeney, B. W., R. L. Vannote, and P. J. Dodds. 1986. The relative importance of temperature and diet to larval development and adult size of the winter stonefly, Soyedina carolinensis (Plecoptera: Nemouridae). Freshwater Biology 16:39-48.

Vannote, R. L., and B. W. Sweeney. 1980. Geographic analysis of thermal equilibria: a conceptual model for evaluating the effect of natural and modified thermal regimes on aquatic insects. American Naturalist 115:667-695.

Vitousek, P. M. 1994. Beyond global warming: ecology and global change. Ecology 75:1861-1876.

Ward, A. F., and D. D. Williams. 1986. Longitudinal zonation and food of larval chironomids (Insecta: Diptera) along the course of a river in temperate Canada. Holarctic Ecology 9:48-57.

Wen, Y. H. 1992. Life history and production of Hyalella azteca (Crustacea: Amphipoda) in a hypereutrophic prairie pond in southern Alberta. Canadian Journal of Zoology 70 : 1417-1424.

Williams, D. D., and I. D. Hogg. 1988. The ecology and production of invertebrates in a Canadian coldwater spring. Holarctic Ecology 11:41-54.

Williams, D. D., and N. E. Williams. 1993. The upstream/ downstream movement paradox of lotic invertebrates: quantitative evidence from a Welsh mountain stream. Freshwater Biology 30:199-218.

Zwick, P. 1992. Stream habitat fragmentation-a threat to biodiversity. Biodiversity and Conservation 1:80-97. 